\title{
Estimating the Root Water Uptake of Surface-Irrigated Apples Using Water Stable Isotopes and the Hydrus-1D Model
}

\author{
Lijian Zheng ${ }^{1}$, Juanjuan Ma ${ }^{1, *}$, Xihuan Sun ${ }^{1,2}$, Xianghong Guo ${ }^{1}$, Qiyun Cheng ${ }^{1}$ and \\ Xiaokai Shi ${ }^{1}$ \\ 1 College of Water Resource Science and Engineering, Taiyuan University of Technology, Taiyuan 030024, \\ China; zhenglijian623@163.com (L.Z.); Sunxihuantyut@163.com (X.S.); Guoxianghongtyut@163.com (X.G.); \\ renrongtyut@163.com (Q.C.); Jiangjingtyut@163.com (X.S.) \\ 2 Jinzhong University, Jinzhong 030600, China \\ * Correspondence: mijsxty@126.com; Tel.: +86-13834556370
}

Received: 11 October 2018; Accepted: 8 November 2018; Published: 10 November 2018

\begin{abstract}
The future production of irrigated fruit orchards in the Loess Plateau of China is threatened by a shortage of freshwater. To improve water use efficiency under conditions where irrigation is limited, it is necessary to quantify the root water uptake (RWU) of apple trees. The RWU of apple trees was estimated under surface irrigation using water stable isotope technology and the Hydrus-1D model. Using the Romero-Saltos and IsoSource models, the stable isotopes of water in stems, different soil depths, and different precipitation were analyzed in a 5-year-old dwarfing apple orchard during two seasons 2016 and 2017. Hydrus-1D model was able to simulate the RWU of apple using the maximum coefficient of determination (0.9), providing a root mean square error of $0.019 \mathrm{~cm}^{3} \mathrm{~cm}^{-3}$ and a relative error of $2.25 \%$. The results showed that the main depth of RWU ranged from $0-60 \mathrm{~cm}$ during the growth season, with the main contribution occurring in the $0-40 \mathrm{~cm}$ depth. These findings indicated that reducing the traditional surface irrigation depth will be important for improving the irrigation water use efficiency.
\end{abstract}

Keywords: water use; hydrogen and oxygen; numerical simulation; surface irrigation; apple; root water uptake

\section{Introduction}

With agricultural water resources around the world experiencing increasing shortages, research that explores how to effectively improve the efficiency of agricultural water use has become essential [1,2]. The apple tree is the main income-generating fruit crop that is grown on the Loess Plateau in China [3]. Apple trees consume high levels of water and are frequently subjected to drought stress [4], so are therefore more dependent on irrigation water to ensure both crop yield and quality [5]. Of the different irrigation techniques used, surface irrigation (SI), such as border irrigation, is the most simple and effective conventional method in China [6]. However, the water use efficiency (WUE) of SI is lower under conditions with higher soil evaporation and deep-water percolation. In these irrigated orchards, the traditional surface irrigation depths frequently exceed $100 \mathrm{~cm}$ [7], however, the fine roots of apple trees are mostly distributed at a depth of 0-40 $\mathrm{cm}$ [8], meaning that deeper soil water may not be utilized. Understanding the root water uptake (RWU) of apples is important to more effectively manage SI.

Water stable isotopes technology is a powerful tool for in situ studies of RWU [9-11] based on the fact that stable isotope fractionation does not normally occur during RWU and stem flow transport in plants $[12,13]$. The RWU of the plant can be measured by quantifying the change in the oxygen and 
hydrogen stable isotopic ratios $\left(\delta^{18} \mathrm{O}\right.$ and $\left.\delta \mathrm{D}\right)$ in the xylem water and in the water in different soil layers. Stable isotope methods have been increasingly applied to identify the RWU in various field crops [14-17] and forest and arid plants [18-21]. The depth of RWU is traditionally measured by direct inference or by using a two-end-member mixing model [22]. However, by using the Romero-Saltos model and IsoSource model [23,24], the depth of RWU and the range of water uptake contributions from different soil layers can be quantified. Currently, few studies have used this technology on fruit trees [25], with only limited studies on jujube [26] and cherry [27], and none specifically on apple trees under SI.

Stable isotopes technology has the disadvantage of having a high cost per measurement and being limited in sampling frequency and soil division [28], making it difficult to estimate RWU continuously and extensively. Hydrodynamic models are useful tools to estimate the water movement in the root-soil profile while considering the different time and spatial intervals [29,30]. With these models, the Richards equation with an RWU term is often used to study the RWU characteristics of plants [31,32]. Among the available numerical models, Hydrus-1D has been widely used to simulate the RWU under different crop types [33,34], water qualities [35], soil types [36], and irrigation methods [37,38], but there are relatively few studies that have used Hydrus-1D to investigate RWU in surface-irrigated apple orchards of arid and semi-arid areas. However, the limitation of this method is that the RWU calculated from the model results contain uncertainty, as models need many parameters and assumed conditions to describe the relationship between the soil water movement and root growth $[39,40]$.

Based on the above considerations, the objectives of this study were to (1) investigate the interaction between soil water and apple trees in a surface-irrigated orchard, and (2) verify the hypothesis that the traditional irrigation depth exceeds the depth of RWU in orchards of China. Water stable isotopes and Hydrus-1D methods were used to quantify the contributions of different soil depths to RWU at a low and high temporal resolution (months to days).

\section{Materials and Methods}

\subsection{Study Site and Experimental Design}

All experiments were conducted in the dwarfing apple interstock orchard at the Shanxi Academy of Agricultural Sciences, located in the Taigu County, Jinzhong City, in the Shanxi Province $\left(37^{\circ} 23^{\prime} \mathrm{N}\right.$, $\left.112^{\circ} 32^{\prime} \mathrm{E}\right)$. The site has a semi-arid climate, with a mean annual air temperature of approximately 9.8 ${ }^{\circ} \mathrm{C}$, and a mean annual precipitation of $460 \mathrm{~mm}$. During the growing season from April to October, the total precipitation of the experiment was 584.4 and $457.4 \mathrm{~mm}$ in 2016 and 2017, respectively (Figure 1).

The 5-year-old apple trees selected for the experiment were chosen with a uniform growth rate and tree diameter. Selected stocks were comprised of "Red Fuji" (Malus domestica Borkh.) section grafted onto Shao series (SH), interstack, and crabapple rootstock (Malus robusta Rehd), which were transplanted in 2015 with inter-row and in-row spacings of $2 \times 4 \mathrm{~m}$. In April 2016 and 2017, surface irrigation (border irrigation equipped with PE pipe, and the width and height of border were $2 \mathrm{~m}$ and $30 \mathrm{~cm}$, respectively) was applied in the experimental site $\left(100 \times 12 \mathrm{~m}^{2}\right.$, including 150 trees). The 6 representative trees selected for this study were completely randomized and located in the middle of the experimental site. According to local irrigation experience, irrigation was performed on 22 April, 1 June, and 6 September in 2016 and on 19 April, 17 May, 19 June, 19 July, and 16 August in 2017. Each irrigation amount was $45 \mathrm{~mm}$ (based on the maximum irrigation depth of $100 \mathrm{~cm}$, and the irrigation limit of $60-90 \%$ of the field capacity $\left.\left(0.3 \mathrm{~cm}^{3} \mathrm{~cm}^{-3}\right)\right)$, while total irrigation amount was $135 \mathrm{~mm}$ in 2016 and $225 \mathrm{~mm}$ and 2017, which accounted for $61 \%$ and $64 \%$ of the calculated crop evapotranspiration (ETc), respectively. The ETc was calculated according to the methodology described in El Jaouhari et al. (2018) [5]. Each year, the trees were fertilized with $600 \mathrm{~kg} \mathrm{ha}^{-1}$ of urea, $150 \mathrm{~kg} \mathrm{ha}^{-1}$ of superphosphate and $100 \mathrm{~kg} \mathrm{ha}^{-1}$ of potassium sulfate. 


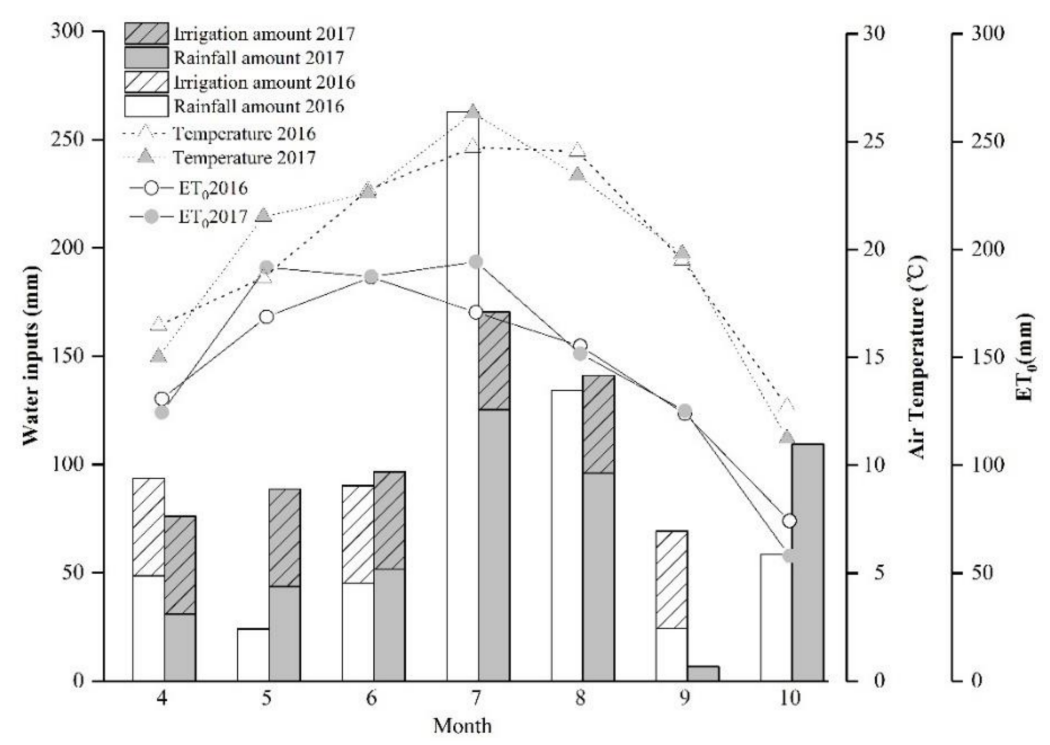

Figure 1. The precipitation, irrigation, air temperature, and reference evapotranspiration $\left(\mathrm{ET}_{0}\right)$ of the apple orchard during the growth seasons of 2016 and 2017.

\subsection{Isotope Sampling and Analysis}

Plant stem and soil samples were collected simultaneously during the growing seasons of 2016 and 2017. Sampling dates were 21 April, 12 May, 16 June, 7 July, 28 August, 29 September, and 17 October in 2016, and 18 April, 15 May, 18 June, 19 July, 16 August, 18 September, and 12 October in 2017. Taking samples only once a month may reflect the seasonal variations in root water uptake. For each tree sampled, $1-5 \mathrm{~cm}$ of lignified twigs were cut from the canopy in the four cardinal directions, and bark and green stem tissues were removed quickly in lower light conditions to avoid the possibility of fractionation of the water stable isotopes. At the same time, soil samples were collected by auger at depths of $0-20,20-40,40-60,60-80,80-100,100-120,120-140$, and 140-160 cm. The location of the soil cores was $50 \mathrm{~cm}$ from the trunk, and four cores $(2 \mathrm{~cm}$ in diameter) were collected, mixed, and the litter was removed to obtain one composite sample per tree. The twigs and soil samples were immediately placed in small vials sealed with Teflon-lined screw caps (Corning, NY, USA) and parafilm (Bemis NA, Neenah, WI, USA). Precipitation water samples were collected in vials through a funnel with a ping-pong ball placed over the spout to avoid fractionation caused by evaporation. All water samples were stored in a cooler with ice and then stored in the laboratory at $-20^{\circ} \mathrm{C}$.

Soil and plant water were extracted by the cryogenic vacuum extraction method at $90^{\circ} \mathrm{C}$ and 1 $\mathrm{Pa}$. After extraction for approximately $2-3 \mathrm{~h}$, the extracted water was pipetted from U-tubes into 2 $\mathrm{mL}$ glass vials for isotopic analysis. The $\delta \mathrm{D}$ and $\delta^{18} \mathrm{O}$ values were measured with a Picarro L2130-i analyzer (Picarro, Santa Clara, CA, USA) and calculated as follows:

$$
\delta^{18} \mathrm{O} \text { or } \delta \mathrm{D}=\left(\frac{\mathrm{R}_{\text {sample }}}{\mathrm{R}_{\text {standard }}}-1\right) \times 1000 \%
$$

where $R_{\text {sample }}$ and $R_{\text {standard }}$ are the ratios of the heavier to the lighter isotope of the sample and standard (Vienna Standard Mean Ocean Water, VSMOW), respectively. A micro-pyrolysis module (A0214) and ChemCorrect post-processing software were employed to remove the interference from organic material and correct the results. The measured values were calibrated to three standard samples (SLAP2, VSMOW2, and GISP) from the International Atomic Energy Agency. The $\delta \mathrm{D}$ and $\delta^{18} \mathrm{O}$ values of the water samples were determined with a precision of \pm 1 and $\pm 0.1 \%$, respectively.

The Romero-Saltos and IsoSource models were selected to analyze RWU [23,24]. The Romero-Saltos model can estimate the mean depth of root water uptake at a given time. It assumes that a given tree could take the uptake water from a normal distribution of a $50 \mathrm{~cm}$ vertical 
segment with a one-centimeter vertical resolution, with the mean depth of RWU at the center of the segment. Based on the principle of isotope mass balance, the IsoSource model is able to determine the range of the proportional contributions from each soil layer to the RWU. The mixture of different soil layers was divided into eight groups (0-20, 20-40, 40-60, 60-80, 80-100, 100-120, 120-140, and $140-160 \mathrm{~cm})$. In this study, the input parameter increments were set as $1 \%$ solution, and a tolerance level of $\pm 0.02 \%$ was counted as a feasible solution. Generally, there was no significant difference between the results obtained from $\delta^{2} \mathrm{H}$ and $\delta^{18} \mathrm{O}$. Therefore, for each model, the $\delta^{18} \mathrm{O}$ value of the stem and soil profile water were used to calculate the mean depth and proportional contributions of RWU.

\subsection{Hydrus-1D Model}

The RWU of surface irrigated apples was simplified into one-dimensional in order to model the vertical RWU using the Hydrus-1D software package [32]. The governing equation for water flow is a modified form of the 1D-Richards equation as follows:

$$
\frac{\partial \theta}{\partial t}=\frac{\partial}{\partial z}\left[K(h) \frac{\partial h}{\partial z}\right]-\frac{\partial K(h)}{\partial z}-S(z, t)
$$

where $\theta$ is the volumetric water content $\left(\mathrm{cm}^{3} \mathrm{~cm}^{-3}\right), t$ is the time (day), $h$ is the soil water pressure head $(\mathrm{cm}), z$ is vertical space coordinate $(\mathrm{cm}), K$ is the hydraulic conductivity coefficient $\left(\mathrm{cm} \mathrm{day}^{-1}\right)$, and $S$ is the RWU rate $\left(\mathrm{L} \mathrm{day}^{-1}\right)$.

Initial conditions in the study were set as the initial water content of the soil profile. The simulation study was conducted from 22 May to 17 October 2016 (from the $112^{\text {th }}$ to the $290^{\text {th }}$ day of the year) at a daily time step. The soil water content was measured weekly using time-domain reflectometry with intelligent micro-elements (TRIME, IMKO, Ettlingen, Germany). The measured soil moisture data from 21 May 2016 were used as the initial condition. The measurements were performed at 20-cm increments from 0 to $160 \mathrm{~cm}, 50 \mathrm{~cm}$ from the trunk. The upper and lower boundary conditions for water flow were described as the "atmospheric boundary condition with surface layer" and "free drainage", respectively.

The soil hydraulic properties were described using van Genuchten-Mualem constitutive relationships, as follows:

$$
\begin{gathered}
\theta(h)=\left\{\begin{array}{r}
\theta_{r}+\frac{\theta_{s}-\theta_{r}}{\left[1+|\alpha h|^{n}\right]^{m},}, h<0 \\
\theta_{s}, h \geq 0
\end{array}\right. \\
K(\mathrm{~h})=\left\{\begin{array}{r}
K_{s} S_{e}^{l}\left[1-S_{e}^{1 / m}\right]^{2}, h<0 \\
K_{s}, h \geq 0
\end{array}\right. \\
S_{e}=\left(\theta-\theta_{r}\right) /\left(\theta_{s}-\theta_{r}\right) \\
m=1-\frac{1}{n}, n>1
\end{gathered}
$$

where $\theta_{s}$ and $\theta_{r}$ are the saturated and residual water contents $\left(\mathrm{cm}^{3} \mathrm{~cm}^{-3}\right)$, respectively, $l$ is the tortuosity parameter, $K_{s}$ is the saturated hydraulic conductivity $\left(\mathrm{cm} \mathrm{day}^{-1}\right), S_{e}$ is the effective saturation, and $\alpha, m$, and $n$ are the empirically fitted parameters. In this study, the soil depth from $0-160 \mathrm{~cm}$ were simplified as homogeneous soil. The soil input parameters are listed in Table 1.

Table 1. The parameters of the model soil solution.

\begin{tabular}{ccccccc}
\hline Depth (cm) & $\boldsymbol{\theta}_{\boldsymbol{r}}$ & $\boldsymbol{\theta}_{\boldsymbol{s}}$ & $\boldsymbol{\alpha}$ & $\boldsymbol{K}_{\boldsymbol{s}}$ & $\boldsymbol{n}$ & $\boldsymbol{l}$ \\
\hline $0-160$ & 0.018 & 0.468 & 0.00939 & 10.6877 & 1.6032 & 0.5 \\
\hline
\end{tabular}


To simulate the $S$ (RWU), the Feddes model was applied without considering the osmotic stress:

$$
\begin{gathered}
S(z, t)=\gamma(h) S_{p}=\gamma(h) b(z) T_{P} \\
\gamma(h)=\left\{\begin{array}{c}
\frac{h_{1}-h}{h_{1}-h_{2}}, h_{2}<h<h_{1} \\
1, h_{3} \leq h \leq h_{2} \\
\frac{h-h_{4}}{h_{3}-h_{4}}, h_{4} \leq h \leq h_{3} \\
0, h_{4} \geq h \text { or } h \geq h_{1} \\
\frac{1.66667}{160}, z \leq 32
\end{array}\right. \\
b(z)=\left\{\begin{array}{c}
z \\
2.0833\left[1-\frac{z}{160}\right], 32 \leq z \leq 160 \\
0, z>160
\end{array}\right. \\
T_{P}=K_{C} E T_{0}\left(1-e^{-k L A I}\right)
\end{gathered}
$$

where $\gamma(h)$ is the water-stress function, the inherent water reduction term is $h_{1}=-10 \mathrm{~cm}, h_{2}=-25 \mathrm{~cm}$, $h_{3 \text { high }}=-500 \mathrm{~cm}, h_{3 \text { low }}=-800 \mathrm{~cm}$, and $h_{4}=-8000 \mathrm{~cm} . b(z)$ is the normalized root density distribution $\left(\mathrm{cm}^{-1}\right), T_{P}$ is the potential transpiration rate $\left(\mathrm{cm} \mathrm{day}^{-1}\right) . K c$ is the crop coefficient, estimated from a fraction of ground cover and plant height [41]. $E T_{0}$ is the reference crop evapotranspiration estimated via the Hargreaves method. $k$ is an extinction coefficient, $k=0.463$. LAI (leaf area index) values were measured during different seasons using an LAI-2200 (LI-COR Inc., Lincoln, NE, USA).

In this study, the Hydrus-1D calibration was performed using the measured soil water content data from 2016. The simulation precision of the model was evaluated using the root-mean-square error (RMSE), relative error (RE), and the coefficient of determination $\left(R^{2}\right)$, which were calculated as follows:

$$
\begin{aligned}
& \mathrm{RMSE}=\sqrt{\sum_{i=1}^{l} \frac{\left(\theta_{i}^{s}-\theta_{i}^{R}\right)^{2}}{l}} \\
& \mathrm{RE}=\left|1-\frac{\sum_{i=1}^{l} \theta_{i}^{s}}{\sum_{i=1}^{l} \theta_{i}^{R}}\right| \times 100 \% \\
& \mathrm{R}^{2}=1-\frac{\sum_{i=1}^{l}\left(\theta_{i}^{s}-\theta_{i}^{R}\right)^{2}}{\sum_{i=1}^{l}\left(\theta_{i}^{R}-\overline{\theta^{R}}\right)^{2}}
\end{aligned}
$$

where $\theta^{s}$ is the simulated soil water content $\left(\mathrm{cm}^{3} \mathrm{~cm}^{-3}\right), \theta^{R}$ is the measured soil water content $\left(\mathrm{cm}^{3}\right.$ $\left.\mathrm{cm}^{-3}\right), \bar{\theta}$ is the average soil water content $\left(\mathrm{cm}^{3} \mathrm{~cm}^{-3}\right)$, and $l$ is the number of points measured.

\subsection{Statistical Data Analysis}

Analysis of Variance (ANOVA) and a correlation analysis were performed using the software package SPSS 17. The parameter normality test for ANOVA was conducted using quantile-quantile $(\mathrm{Q}$ - Q) plots in SPSS. Logarithmic transformation was required if the distribution was not normal. The least significant difference (LSD) test was used to compare means and the differences were considered significant at a level of $p<0.05$. 


\section{Results and Discussion}

\subsection{Isotopic Composition of Precipitation, Soil and Stem Water}

During the apple's growth seasons during 2016 and 2017, the stable isotopic values of precipitation water varied sharply (ranging from $-0.6 \%$ to $-18.9 \%$ for $\delta^{18} \mathrm{O}$ and from $-8.1 \%$ to $-136.7 \%$ for $\delta \mathrm{D}$ in 2016 , and from $-2.7 \%$ to $-18.7 \%$ for $\delta^{18} \mathrm{O}$, and from $-14.7 \%$ to $-138.9 \%$ for $\delta \mathrm{D}$ in 2017 ). The local meteoric water line (LMWL) fitted by the $\delta^{18} \mathrm{O}$ and $\delta \mathrm{D}$ of precipitation water was $\delta \mathrm{D}=7.48 \times \delta^{18}+$ $2.43\left(\mathrm{R}^{2}=0.971\right)$ in 2016 , which lay below the global meteoric water line $\left(\mathrm{GMWL}, \delta \mathrm{D}=8 \times \delta^{18} \mathrm{O}+\right.$ 10). The slope of LMWL would coincide with that of GMWL without the effect of evaporation, but in this study, the lower slope showed that atmospheric rainfall was greatly affected by evaporation during the landing process. Compared with 2016, the slope of LMWL (Figure 2) in 2017 was slightly lower because of higher air temperatures and lower humidity (Figure 1). The LMWL established by Wang et al. [15] $\left(\delta \mathrm{D}=7.45 \times \delta^{18} \mathrm{O}+1.74\right)$ and by Guo et al. $\left(\delta \mathrm{D}=7.78 \times \delta^{18} \mathrm{O}+2.38\right)$ [42], in the southern Shanxi Province and in the Beijing area $\left(\delta \mathrm{D}=7.50 \times \delta^{18} \mathrm{O}+4.20\right)$ [27] are similar to results from this study.

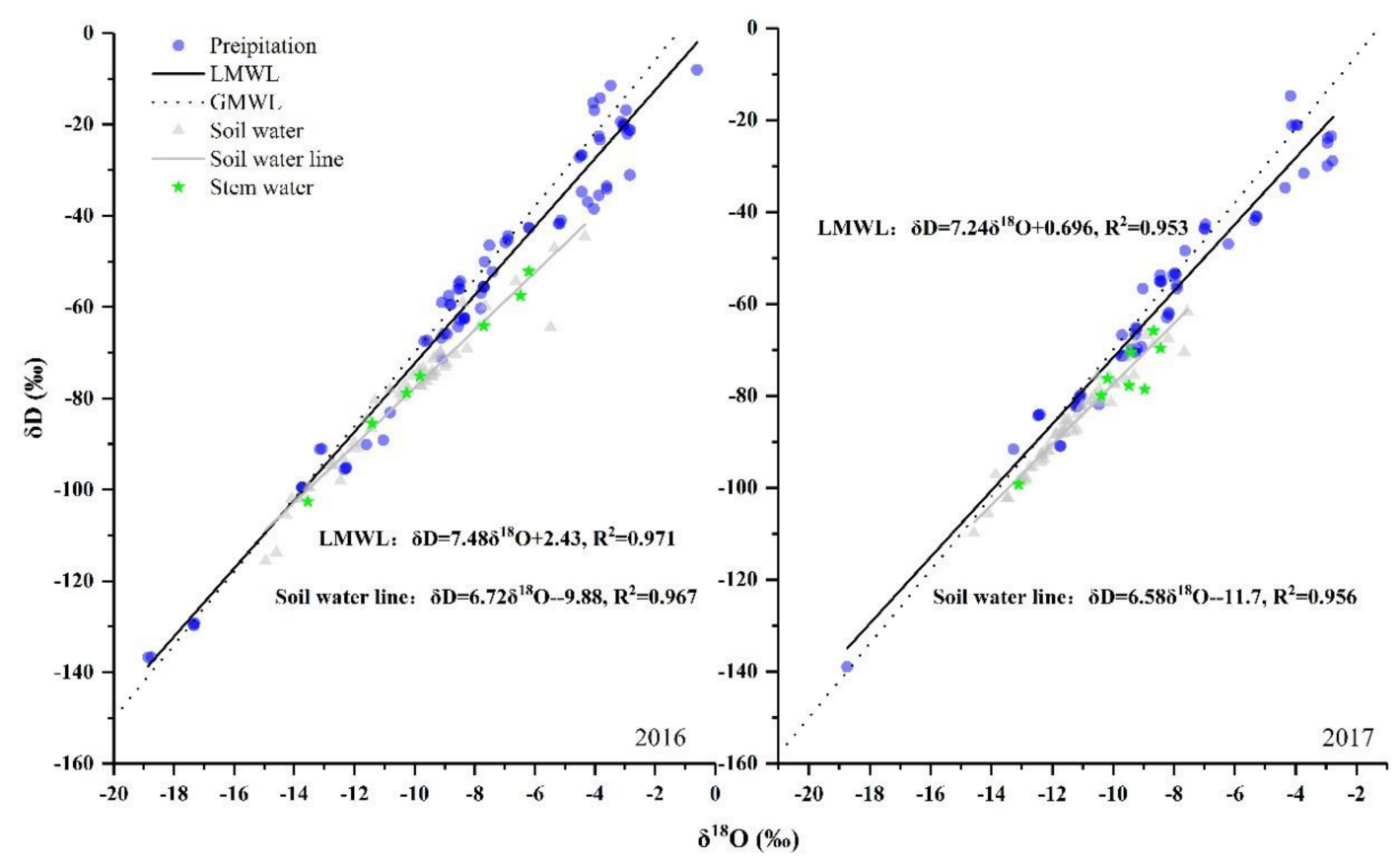

Figure 2. The correlation between $\delta^{18} \mathrm{O}$ and $\delta \mathrm{D}$ values of precipitation, different soil depths, and stem water in 2016 and 2017.

For both growth seasons, the $\delta^{18} \mathrm{O}$ values of soil water varied between $-4.3 \%$ and $-14.9 \%$, and the $\delta \mathrm{D}$ values of soil water varied between $-44.6 \%$ and $-115.6 \%$. The slope of the soil water line was less than that of LMWL, which indicated the strong effect of evaporation on soil water in this area. When there was more vigorous fractionation along the depth of the soil profile, it became easier to distinguish the contribution from different soil depths. Figure 2 shows that the isotopic values of stem waterfall around these values of soil water. It indicated that the water source of apple trees come from the soil, while the precipitation must be converted to the soil water to be absorbed by roots [43].

\subsection{The Depth of RWU and the Proportional Contribution of Soil Water to Apple Trees}

Table 2 shows the mean depth of RWU as calculated by the Romero-Saltos model. Our Results agreed with other studies that showed that the use of different soil segments did not affect the final results [21,23], as no differences were seen between soil segments from 40,50, and $60 \mathrm{~cm}$. The depth 
of RWU during the growth season in both 2016 and 2017 ranged from $15-55 \mathrm{~cm}$. For both years, the depth of RWU gradually increased from April to June as the water requirement of the apple trees increased [44]. During July and August, precipitation accounted for an average of $57 \%$ of the total amount of precipitation during the growth season and the depth of RWU stabilized within the first $40 \mathrm{~cm}$. Sun et al. [45] also found that the upper soil layer $(0-30 \mathrm{~cm})$ contributed to $68 \%$ of the total tree water in the wet season. From September to October, the depth of RWU decreased to $45 \mathrm{~cm}$.

Table 2. The mean depth of root water uptake (RWU) in surface-irrigated apple using the Romero-Saltos model.

\begin{tabular}{ccc}
\hline \multirow{2}{*}{ Month } & \multicolumn{2}{c}{ The Mean Depth of RWU (cm) } \\
\cline { 2 - 3 } & $\mathbf{2 0 1 6}$ & $\mathbf{2 0 1 7}$ \\
\hline April & 16.99 & 26.98 \\
May & 23.60 & 31.53 \\
June & 26.55 & 51.26 \\
July & 27.43 & 34.36 \\
August & 36.82 & 27.03 \\
September & 42.99 & 34.24 \\
October & 30.34 & 36.68 \\
\hline
\end{tabular}

Using the IsoSource method, the mean proportional contribution to RWU during the two seasons from different soil layers is shown in Figure 3. The RWU was concentrated in the first $0-40 \mathrm{~cm}$ for $67.7 \%$ of the time (average of both years). The $0-20 \mathrm{~cm}$ soil layer contributed the maximum to RWU during the growth season, except for October of 2017, with average contributions of $59.7 \%$ in 2016 and $53.1 \%$ in 2017 . The contribution from the $0-20 \mathrm{~cm}$ layers decreased as the season progressed, while the contribution from the $20-40 \mathrm{~cm}$ layer increased from $3.3 \%$ to $14.7 \%$ in 2016 , and from $6 \%$ to $36.5 \%$ in 2017 ; and the $40-60 \mathrm{~cm}$ layer increased from $1.6 \%$ to $11.9 \%$ in 2016 , and from $2.7 \%$ to $16.6 \%$ in 2017, respectively.

In 2017, after the 100-mm continuous rainfall event from 2 to 9 of October, the main RWU was measured on $12^{\text {th }}$ of October and was not found to be concentrated in the $0-20 \mathrm{~cm}$ soil layer as the results of 2016. This implies that either, (1) the higher soil water content would inhibit the root activity and RWU, as in this study, in the highest soil water content from $0-20 \mathrm{~cm}$ was $0.29 \mathrm{~cm}^{3} \mathrm{~cm}^{-3}$ (accounting for $97 \%$ of field capacity). Gong et al. [46] also illustrated that the main root water uptake of apple was $40-100 \mathrm{~cm}$ after continuous rainy days. Or, alternatively, (2) the stability of water source is important for the strategy of RWU. For example, studies have demonstrated that riparian trees prefer to use more stable water sources such as groundwater, as opposed to surface water [12,41]. 


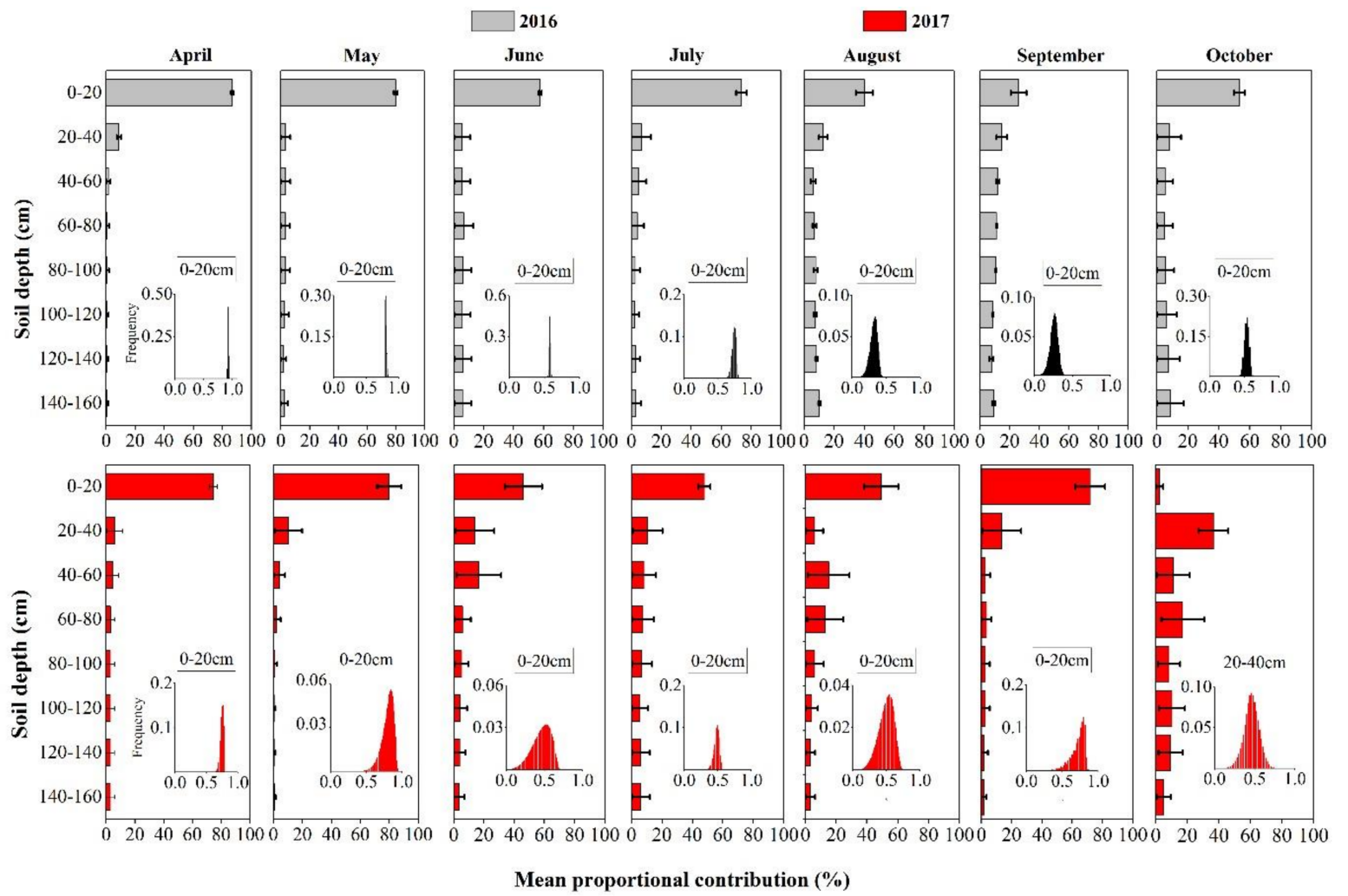

Figure 3. The proportions of soil water contributions at different months in the 2016 and 2017 seasons. The frequency histograms show the estimated ranges of proportional contributions of water from the main soil depth to the total apple water uptake, the $\mathrm{x}$-axis was the proportional contribution from 0 to 1 , and the $y$-axis was the frequency. The error bars are the standard deviation.

\subsection{Evaluation of Models of the RWU Rate for Apples at Different Soil Depths}

As shown in Figure 4, the simulated values fit well with the measured values. The slope of the linear equations from $0-160 \mathrm{~cm}$ ranged from 0.922 to 1.22 , and the coefficients of determination $\left(\mathrm{R}^{2}\right)$ ranged from 0.759 to 0.924 . The RMSEs at different soil depths were not higher than 0.019 , and their REs were not higher than $2.25 \%$, which were classified as an acceptable range [47]. In this study, the established Hydrus-1D model had a high degree of accuracy when simulating soil water infiltration processes in surface-irrigated apple orchards.

Figure 5 illustrates that the RWU of apples decreased sharply with depth and that most uptake occurred in the upper soil layer. The main range and intensity of RWU of apple initially increased then subsequently decreased over time and reached the maximum during July. The RWU rate was higher in the $0-60 \mathrm{~cm}$ soil layer and accounted for an average of $60 \%$ of the total RWU rate during both seasons. Using a numerical model, Green and Clothier [48] also found that when surface soil layers were uniformly wet, $70 \%$ of mature apple trees' RWU occurred in the top $40 \mathrm{~cm}$ of the root zone. Besharat et al. [49] showed that the maximum RWU was at a depth of 10-50 cm using the 2-dimensional model of apple trees. 


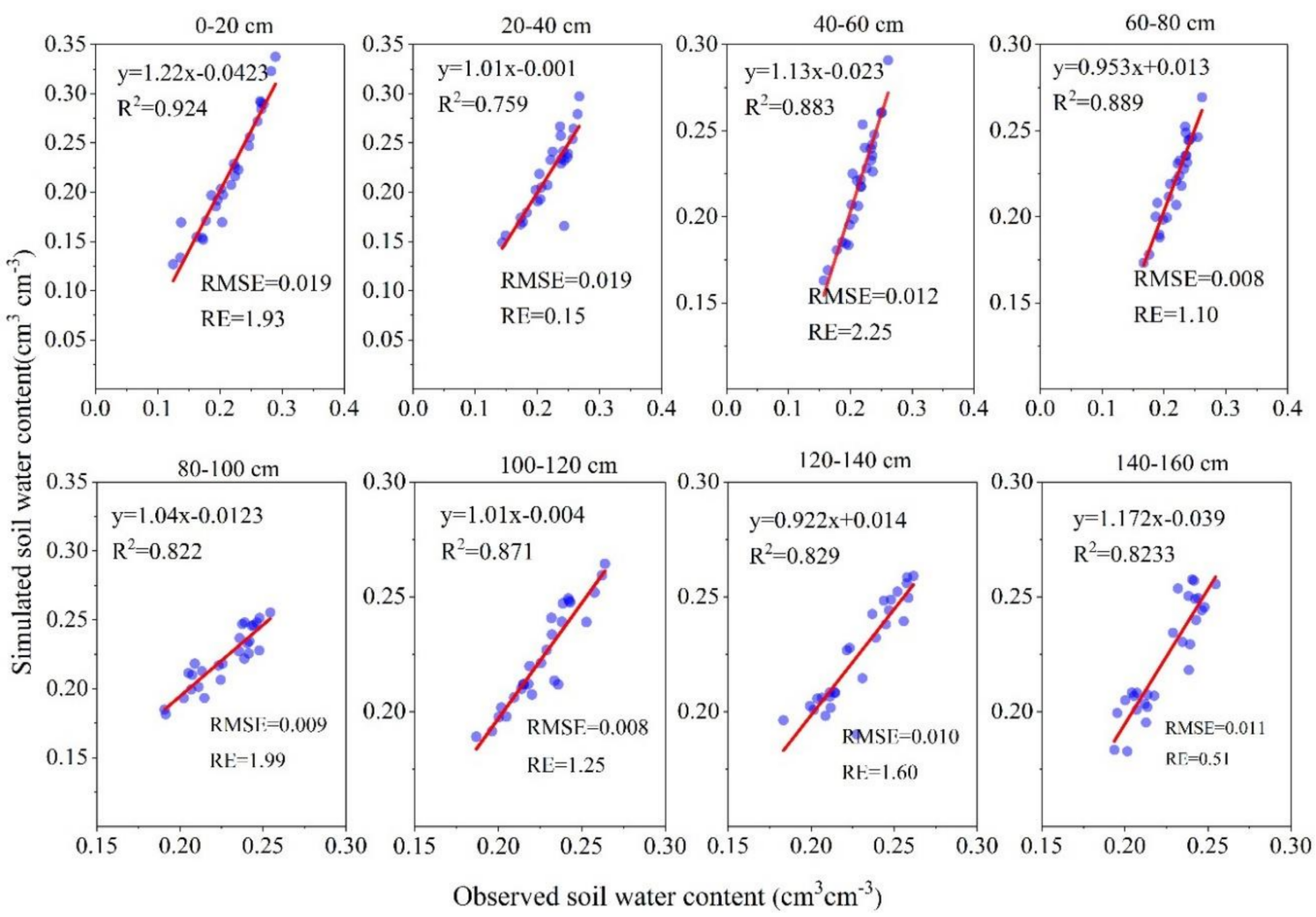

Figure 4. The linear relationship between the experimental and simulated values of soil water content at different soil depths. The root mean square error (RMSE), relative error (RE), and coefficient of determination $\left(\mathrm{R}^{2}\right)$ are shown.

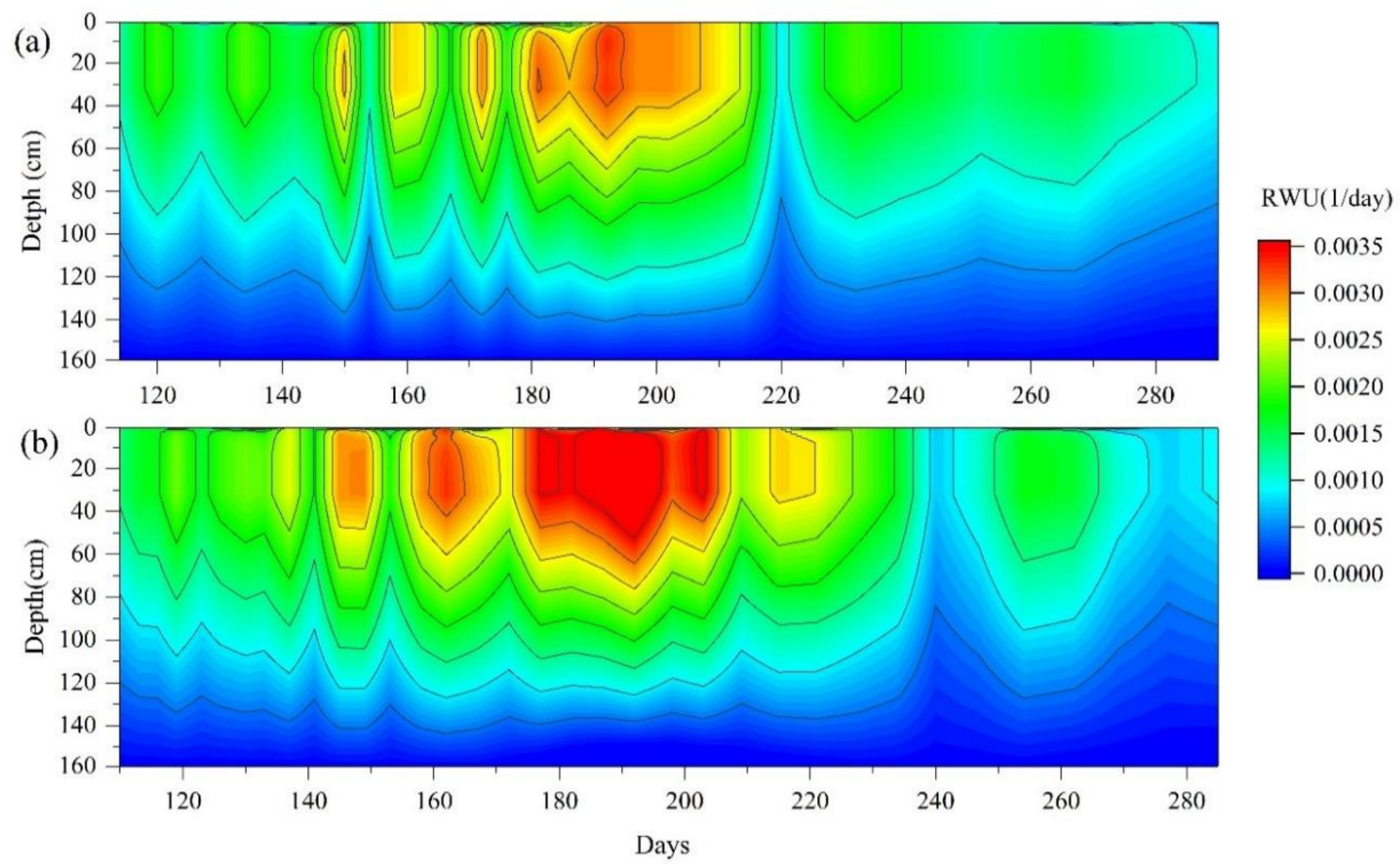

Figure 5. The dynamics of the RWU rate in apples at different soil depths during 2016 (a) and 2017 (b).

Compared with the results by the isotopic method, in the October 9 of 2017 (Figure 5b), we did not find the increasing rate in the $20-40 \mathrm{~cm}$ layer than that of 0-20 cm. In this study, the root distribution 
was considered by the Hydrus-1D model. However, the morphological structure of roots cannot always represent the RWU ability $[15,16]$. Thus, RWU cannot be indicated solely by relying on root distribution $[17,44]$. Further studies are therefore needed to consider the effect of water stability on our model, and it would be better to use a deuterium or oxygen-based labeling technique [10] to further study that phenomenon.

Over two years of data were gathered to estimate the main depth of an apple tree's RWU under SI. The $\delta^{18} \mathrm{O}$ and Hydrus-1D methods were used to analyze variations in the RWU given the field data, which ranged from 0-60 cm during the growth season, but was concentrated at depths of 0-40 cm depth. Although apples are deep-rooted [3], the zone of RWU was in the shallow profile under surface irrigation in this study. For this reason, a deep irrigation depth of surface irrigation would increase the percolation below the root zone. Compared with the traditional irrigation depth of $100 \mathrm{~cm}$, each irrigation amount of a dwarfing apple tree could save about $60 \%$ of water if the irrigation depth is assumed to be $40 \mathrm{~cm}$ and the irrigation limit is assumed to be $60-90 \%$ of the field capacity $\left(0.3 \mathrm{~cm}^{3} \mathrm{~cm}^{-3}\right)$ used by drip or sprinkle irrigation. On the other hand, it is hard to resist a continuing drought for the shallow RWU of trees via less irrigation water in the Loess Plateau of China. Therefore, developing water-saving irrigation systems (such as subsurface drip irrigation and partial root-zone wetted irrigation), which could improve the RWU and soil water availability in the deeper soil profile, will be necessary to achieve the efficient utilization of water resources.

\section{Conclusions}

Surface irrigation is commonly used for dwarfing apple orchards in the major apple production areas in China. Under the present irrigation practices, the main depth of RWU of an apple tree is 0-60 cm using the water stable isotopes technology and Hydrus-1D model. The results suggest that the soil layer from $0-40 \mathrm{~cm}$ was the main zone that contributed to the RWU. To increase the irrigation efficiency for apple in this region, these results suggest that by reducing the irrigation depth, the water-savings can be increased. These findings are important for planning optimal agricultural water management practice and irrigation schedules in apple orchards in the Loess Plateau in China.

Author Contributions: L.Z. conceived and designed the experiments and model; J.M. and X.S. reviewed the manuscript and made helpful suggestions; X.G. contributed materials tools and model; L.Z., Q.C., and X.S. performed the experiment.

Funding: This work was supported by the Chinese National Natural Science Foundation (grant numbers 51579168), and the Natural Science Foundation of Shanxi Province (grant numbers 2016D011053).

Conflicts of Interest: The authors declare no conflict of interest.

\section{References}

1. Elnmer, A.; Khadr, M.; Allam, A.; Kanae, S.; Tawfik, A. Assessment of irrigation water performance in the nile delta using remotely sensed data. Water 2018, 10, 1375. [CrossRef]

2. Elliotte, J.; Deryng, D.; Muller, C.; Frieler, K.; Konzmann, M.; Gerten, D.; Glorrer, M.; Florke, M.; Wada, Y.; Best, N. Constraints and potentials of future irrigation water availability on agricultural production under climate change. Proc. Natl. Acad. Sci. USA 2014, 111, 3239-3244. [CrossRef] [PubMed]

3. Song, X.L.; Gao, X.D.; Dyck, M.; Zhang, W.; Wu, P.T.; Yao, J.; Zhao, X.N. Soil water and root distribution of apple tree (Malus Pumila Mill) stands in relation stand age and rainwater collection and infiltration system (RWCI) in a hilly region of the loess Plateau, China. Catena 2018, 170, 324-334. [CrossRef]

4. Li, H.C.; Gao, X.D.; Zhao, X.N.; Wu, P.T.; Li, L.S.; Ling, Q.; Sun, W.H. Integrating a mini catchment with mulching for soil water management in a sloping jujube orchard on the semiarid loess plateau of China. Solid Earth 2016, 7, 167-175. [CrossRef]

5. EI Jaouhari, N.; Abouabdillah, A.; Bouaid, R.; Bouring, M.; Aleya, L.; Chaoui, M. Assessment of sustainable deficit irrigation in a Moroccan apple orchard as a climate change adaptation strategy. Sci. Total Environ. 2018, 642, 574-581. [CrossRef] [PubMed] 
6. Wang, X.P.; Zhang, X.X.; Wang, L. Experimental study on movement law of rapid available phosphorus in root area of apple tree under border irrigation. Water Sav. Irrig. 2013, 3, 1-4.

7. Yang, B.; Wen, X.F.; Sun, X.M. Irrigation depth far exceeds water uptake depth in an oasis cropland in the middle reaches of Heihe River Basin. Sci. Rep. 2015, 5, 15206. [CrossRef] [PubMed]

8. An, H.S.; Luo, F.X.; Wu, T.; Wang, Y.; Xu, X.F.; Zhang, X.Z.; Han, Z.H. Dwarfing effect of apple rootstocks is intimately associated with low number of fine roots. Hortscience 2017, 52, 503-512. [CrossRef]

9. Thorburn, P.J.; Ehleringer, J.R. Root water uptake of field-growing plants indicated by measurements of natural-abundance deuterium. Plant Soil 1995, 177, 225-233. [CrossRef]

10. Kulmatiski, A.; Bead, K.H. Woody plant encroachment facilitated by increased precipitation intensity. Nat. Clim. Chang. 2013, 3, 833-837. [CrossRef]

11. Rothfuss, Y.; Javaux, M. Reviews and syntheses: Isotopic approaches to quantify root water uptake: A review and comparison of methods. Biogesciences 2017, 14, 2199-2224. [CrossRef]

12. Dawson, T.E.; Ehleringer, J.R. Streamside trees do not use stream water. Nature 1991, 350, 334-337. [CrossRef]

13. Lin, G.H.; Sternberg, L.; Ehleringer, J.; Hall, A.; Farquhar, G. Hydrogen Isotopic Fractionation by Plant Roots during Water Uptake in Coastal Wetland Plants, Stable Isotopes and Plant Carbon-Water Relations; Academic Press: Cambridge, MA, USA, 1993; pp. 497-510.

14. Araki, H.; Iijima, M. Stable isotope analysis of water extraction from subsoil in upland rice (Oryza sativa L.) as affected by drought and soil compaction. Plant Soil 2007, 270, 147-157. [CrossRef]

15. Wang, P.; Song, X.F.; Han, D.M.; Zhang, Y.H.; Liu, X. A study of root water uptake of crops indicated by hydrogen and oxygen stable isotopes: A case in Shanxi province, China. Agric. Water Manag. 2010, 97, 475-482. [CrossRef]

16. Zhang, C.Z.; Zhang, J.B.; Zhao, B.Z.; Zhu, A.N.; Zhang, H.; Huang, P.; Li, X.P. Coupling a two-tip linear mixing model with $\delta^{2} \mathrm{H}$ and $\delta^{18} \mathrm{O}$ plot to determine water sources consumed by maize during different growth stages. Field Crop Res. 2011, 123, 196-205. [CrossRef]

17. Shen, Y.J.; Zhang, Z.B.; Gao, L.; Peng, X. Evaluating contribution of soil water to paddy rice by stable isotopes of hydrogen and oxygen. Paddy Water Environ. 2015, 13, 125-133. [CrossRef]

18. Eggemever, K.D.; Awada, T.; Harvey, F.E.; Wedin, D.A.; Zhou, X.; Zanner, C.W. Seasonal changes in depth of water uptake for encroaching trees Juniperus virginiana and Pinus ponderosa and two dominant $\mathrm{C}_{4}$ grasses in a semiarid grassland. Tree Physiol. 2009, 29, 157-169. [CrossRef] [PubMed]

19. Grossiord, C.; Gessler, A.; Granier, A.; Berger, S.; Brechet, C.; Hentschel, R.; Scherer-Lorenzen, M.; Bonal, D. Impact of interspecific interactions on the soil water uptake depth in a young temperate mixed species plantation. J. Hydrol. 2014, 519, 3511-3519. [CrossRef]

20. Chen, J.; Xu, Q.; Gao, D.Q.; Song, A.Y.; Hao, Y.G.; Ma, Y.B. Different water use strategies among selected rare and endangered species in west ordos desert of China. J. Plant Ecol. 2016, 660-669.

21. Stahl, C.; Herault, B.; Rossi, V.; Burban, B.; Brechet, C.; Bonal, D. Depth of soil water uptake by tropical rainforest trees during dry periods: Does tree dimension matter? Oecologia 2013, 173, 1191-1201. [CrossRef] [PubMed]

22. Brunel, J.P.; Walker, G.R.; Kennett-Smith, A.K. Field validation of isotopic procedures for determining sources of water used by plants in a semi-arid environment. J. Hydrol. 1995, 167, 351-368. [CrossRef]

23. Romero-Saltos, H.; Sternberg, L.S.L.; Moreia, M.Z.; Nepstad, D.C. Rainfall exclusion in an eastern Amazonian forest alters soil water movement and depth of water uptake. Am. J. Bot. 2005, 92, 443-455. [CrossRef] [PubMed]

24. Phillips, D.L.; Gregg, J.W. Source partitioning using stable isotopes: Coping with too many sources. Oecologia 2003, 136, 261. [CrossRef] [PubMed]

25. Zhang, Z.Q.; Si, B.C.; Li, Z.; Evaristo, J.; Mcdonnnell, J.J. Tritium analysis shows apple trees may be transpiring water several decades old. Hydrol. Process. 2017, 31, 1196-1201. [CrossRef]

26. Zhu, J.F.; Liu, J.T.; Lu, Z.H.; Xia, J.B.; Sun, J.K.; Shao, H.B.; Zhao, Y.Y. Soil-water interacting use patterns driven by Ziziphus jujube on the Chenier Island in the Yellow River Delta, China. Arch. Agron. Soil Sci. 2016, 62, 1614-1624. [CrossRef]

27. Cao, X.Q.; Yang, P.L.; Engel Bernard, A.; Li, P.F. The effects of rainfall and irrigation on cherry root water uptake under drip irrigation. Agric. Water Manag. 2018, 197, 9-18. [CrossRef]

28. Oerter, E.J.; Bowen, G. In situ monitoring of $\mathrm{H}$ and $\mathrm{O}$ stable isotopes in soil water reveals ecohydrologic dynamics in managed soil systems. Ecohydrology 2017, 10, 1841. [CrossRef] 
29. Kumar, R.; Jat, M.K.; Shankar, V. Evaluation of modeling of water ecohydrologic dynamics in soil-root system. Ecol. Model. 2013, 269, 51-60. [CrossRef]

30. Perers, A. Modified conceptual model for compensated root water uptake-A simulation study. J. Hydrol. 2016, 534, 1-10. [CrossRef]

31. Skaggs, T.H.; van Genuchten, M.T.; Shouse, P.J.; Poss, J.A. Macroscopic approaches to root water uptake as a function of water and salinity stress. Agric. Water Manag. 2006, 86, 140-149. [CrossRef]

32. Simunek, J.; Sejna, M.; Saito, H.; Sakai, M.; van Genuchten, M.T. The Hydrus-1D Software Package for Simulating the One-Dimensional Movement of Water, Heat, and Multiple Solutes in Variably-Saturated Media Version 4.0; University of California Riverside: Riverside, CA, USA, 2008.

33. Forkutsa, I.; Sommer, R.; Shirokova, Y.I.; Lamers, J.P.A.; Kienzler, K.; Tischbein, B.; Martius, C.; Vlek, P.L.G. Modeling irrigated cotton with shallow groundwater in the Aral Sea basin of Uzbekistan. Irrig. Sci. 2009, 27, 319-330. [CrossRef]

34. Deb, S.K.; Shukla, M.K.; Mexal, J.G. Numerical modeling of water fluxes in the root zone of a mature pecan orchard. Soil Sci. Soc. Am. J. 2011, 75, 1667-1680. [CrossRef]

35. Li, H.J.; Yi, J.; Zhang, J.G.; Zhao, Y.; Si, B.C.; Hill, R.L.; Cui, L.L.; Liu, X.Y. Modeling of soil water and salt dynamics and its effects on root water uptake in Heihe Arid Wetland, Gansu, China. Water 2015, 7, 2382-2401. [CrossRef]

36. Zeng, W.Z.; Lei, G.Q.; Zha, Y.Y.; Fang, Y.H.; Wu, J.W.; Huang, J.S. Sensitivity and uncertainty analysis of the hydrus-1d model for root water uptake in saline soils. Crop Pasture Sci. 2018, 69, 163-173. [CrossRef]

37. Zheng, C.; Lu, Y.D.; Guo, X.H.; Li, H.H.; Sai, J.M.; Liu, X.H. Application of HYDRUS-1D model for research on irrigation infiltration characteristics in arid oasis of northwest China. Environ. Earth Sci. 2017, 76, 785. [CrossRef]

38. Jha, S.K.; Gao, Y.; Liu, H.; Huang, Z.D.; Wang, G.S.; Liang, Y.P.; Duan, A.W. Root development and water uptake in winter wheat under different irrigation methods and scheduling for North China. Agric. Water Manag. 2017, 182, 139-150. [CrossRef]

39. Arbat, G.; Puig-Bargués, J.; Barragán, J.; Bonany, J.; de Cartagena, F.R.; Cartagena, F. Monitoring soil water status for micro-irrigation management versus modelling approach. Bio. Eng. 2008, 100, 286-296. [CrossRef]

40. Haride, M. Two dimensional modelling of nitrate flux in a commercial apple orchard. Soil Sci. Soc. Am. J. 2017, 81, 1235-1246. [CrossRef]

41. Allen, R.G.; Pereira, L.S. Estimating crop coefficients from fraction of ground cover and height. Irrig. Sci. 2009, 28, 17-34. [CrossRef]

42. Guo, F.; Ma, J.J.; Zheng, L.J.; Sun, X.H.; Guo, X.H.; Zhang, X.L. Estimating distribution of water uptake with depth of winter wheat by hydrogen and oxygen stable isotopes under different irrigation depths. J. Integer. Agric. 2016, 15, 891-906. [CrossRef]

43. Ma, Y.; Song, X.F. Using stable isotopes to determine seasonal variations in water uptake of summer maize under different fertilization treatments. Sci. Total Environ. 2016, 550, 471-483. [CrossRef] [PubMed]

44. Volschenk, T. Evapotranspiration and crop coefficients of Goldern Delicious/M793 apple trees in the Koue Bokkeveld. Agric. Water Manag. 2017, 194, 184-191. [CrossRef]

45. Sun, S.J.; Meng, P.; Zhang, J.S.; Wan, X.C. Variation in soil water uptake and its effect on plant water status in Juglans regia L. during dry and wet seasons. Tree Physiol. 2011, 31, 1378-1389. [CrossRef] [PubMed]

46. Gong, D.Z.; Kang, S.Z.; Zhang, L.; Du, T.S.; Yao, L.M. A two-dimensional model of root water uptake for single apple trees and its verification with sap flow and soil water content measurements. Agric. Water Manag. 2006, 83, 119-129. [CrossRef]

47. Han, M.; Zhao, C.Y.; Feng, G.; Yan, Y.Y.; Sheng, Y. Evaluating the effects of mulch and irrigation amount on soil water distribution and root zone water balance using Hydrus-2D. Water 2015, 7, 2622-2640. [CrossRef]

48. Green, S.; Clothier, B. The root zone dynamics of water uptake by a mature apple tree. Plant Soil 1999, 206, 61-77. [CrossRef]

49. Besharat, S.; Nazemi, A.H.; Sadraddini, A.A. Parametric modeling of root length density and root water uptake in unsaturated soil. Turk. J. Agric. For. 2010, 34, 439-449.

(C) 2018 by the authors. Licensee MDPI, Basel, Switzerland. This article is an open access article distributed under the terms and conditions of the Creative Commons Attribution (CC BY) license (http:/ / creativecommons.org/licenses/by/4.0/). 